\title{
The 21st Century Instruction: The Relationship between Learning Style and Media Using
}

\author{
Sayamon Insaard
}

\begin{abstract}
This research aimed to 1) study the learning style of the students, 2) study the media using of the students, 3) study the relationship between the learning style and media using. The 191 samples were undergraduate students from the faculty of Education, Ramkhamhaeng University who were studying in the first semester of $\mathbf{2 0 1 7}$ academic year, derived from volunteer sampling. The research instruments were questionnaire on media using, and perceptual learning style preference questionnaire (PLSPQ). The data was statistically analyzed by percentage, mean $(\bar{x})$, standard deviation (S.D.), t-test for independent samples, and Pearson's correlation coefficient. The research findings were that 1 . Three ranks of learning styles of undergraduate students of Ramkhamhaeng University were 1) Kinesthetic Major Learning Style Preference (KLS) $(\bar{x}=4.08$, S.D.= 0.56) 2) Auditory Major Learning Style Preference (ALS) $(\bar{x}=4.06$, S.D. $=0.52)$, and 3) Group Major Learning Style Preference (GLS) $(\bar{x}=4.06$, S.D. $=0.65)$ respectively. 2 . Three most favorite media using of undergraduate students of Ramkhamhaeng University were 1) lecturing of the professors $(\bar{x}=4.30$, S.D. $=0.73), 2)$ printed media, textbooks, and documents $(\bar{x}=4.17$, S.D. $=0.76)$, and 3) PowerPoint presentation $(\bar{x}=\mathbf{4 . 1 6}$, S.D. $=0.82)$. 3 . The relationship between the learning styles of Ramkhamhaeng University undergraduate students was that visual learning style (VLS), tactile learning style (TLS), individual learning style (ILS), ALS, KLS, and GLS significantly related to all types of media using at the level of .01, and individual learning style (ILS) had no relationship to the lecturing of professors.
\end{abstract}

Index Terms-Learning styles, instructional media, PLSPQ.

\section{INTRODUCTION}

Ramkhamhaeng University is one of open university in Thailand. The number of students' recruitment is unlimited and do not have to test. The instructional system is open university and study in the class as the normal system but no force to participate the class. The educational system of open university opens the opportunity for the students to choose the learning method that suited to the students' need. The university provide the lecture for the learners to join the class. But some of the field of study needs to study and discuss with the instructors closely. Some field of study needs to practice so the students need to participate and interact between leaners and instructors. Some department of the faculty identified the students to participate in a class. The samples for this research were the students in the Faculty of Education

Manuscript revised October 10, 2017; revised April 1, 2018.

S. Insaard is with the Department of Educational Technology, Faculty of Education, Ramkhamhaeng University, Bangkapi, Thailand (e-mail: dr.sayamon@gmail.com). who are being trained to be a teacher. In addition, the university provides distance education for individually study and use educational technology to support learning management. The varieties of technology are used for the students who cannot attend the class. And the students who need a revision for studying can use the technology of distance learning such as video, printed materials, textbooks, e-Learning, M-Learning, e-Book, e-Audio Book, Course on Demand, YouTube media, RU Channel, lectured DVD etc. Moreover, the university provides a classroom and instructional media such a lecturer, PowerPoint, video, White Board, Visualizer, television, learning activities, etc. Those of materials and instructional media are used to the learners with any different learning style. In this research, the researcher studied the learning styles of learners and relationship to the media using of instructors in the $21^{\text {st }}$ century and make understanding on individualization in thinking style and learning styles and to adapt the strategy of media use potentially and provide efficiently educational system in terms of knowledge market.

\section{RESEARCH OBJECTIVES}

1) To study the learning style of undergraduate students, Faculty of Education, Ramkhamhaeng University.

2) To study the media using of undergraduate students, Faculty of Education, Ramkhamhaeng University.

3) To study the relationship between learning styles and media using of undergraduate students, Faculty of Education, Ramkhamhaeng University.

\section{RESEARCH HYPOTHESIS}

Learning styles related to media using of undergraduate students, Faculty of Education, Ramkhamhaeng University significantly at the level of .01

\section{RESEARCH METHOdOLOGY}

A survey research on the 21st century instruction: the relationship between learning style and media using has a research methodology as follow:

\section{A. Samples}

The 191 samples of this research were the undergraduate students, who were studying in the $1^{\text {st }}$ semester of 2017 academic year, faculty of education, Ramkhamhaeng University, derived from volunteer sampling.

\section{B. Variables}

Dependent variables were learning style of 6 types; 1) 
VSL- Visual Learning Style 2) ALS- Audio Learning Style 3) TLS- Tactile Learning Style 4) KLS- Kinesthetic Learning Style 5) ILS- Individual Learning Style 6) GLS- Group Learning Style

Independent variables: media using

\section{Research Instruments}

Research Instruments were questionnaire for learning style and media using consisted of 3 sections:

Section 1 Basic information of the students - the description of question was checklist with 5 items

Section 2 Perceptual Learning Style Preference Questionnaire: PLSPQ) [1] - the questions were 5 level rating scale with 30 items. The questions concerned 4 types of perception use; VSL- Visual Learning Style, ALS - Audio Learning Style, TLS - Tactile Learning Style, KLS Kinesthetic Learning Style and Social Aspects learning styles (ILS - Individual Learning Style and GLS - Group Learning Style)

Section 3 The questionnaire on types of media for developing learning was 5level of rating scale with 15 items. The questionnaire was qualified by 5 experts by evaluating the quality of the instrument on content validity using IOC (Index of Item Objective Congruence). The IOC of any item should be more than 0.5 (IOC $1 \geq 0.5$ ) to be accepted for using as a research instrument.

\section{Data Collection}

The data was collected from 1-30 August 2017 by 200 volunteers (samples). The questionnaires were collected and checked before data analysis. It was found $95.50 \%$ were completed and used for data analysis.

\section{E. Data Analysis - The Data Was Analyzed Statistically as Follow:}

1) The analysis of basic information of the samples was analyzed by frequency tally and percentage.

2) The analysis of perceptual learning style preference questionnaire: LSPQ was analyzed and translated the data analysis as follow: a score of learning style $=\operatorname{mix}$ score number of questions in any learning style $\mathrm{x} 2$

Level of learning style score was classified into 3 groups Score 38-50 - Major Learning Style Preference Score 25-37 - Minor Learning Style Preference Score 0-24 - Negligible Learning Style Preference

3) The analysis of opinion level and the data dispersion by mean $(\bar{x})$, standard deviation had a criteria as follow: $4.50-5.00$ refers to agree at the level of "most" $3.50-4.49$ refers to agree at the level of "much" $2.50-3.49$ refers to agree at the level of "average"

$1.50-2.49$ refers to agree at the level of "little"

$1.00-1.49$ refers to agree at the level of "least"

4) The hypothesis test between the variables used t-test Independent

5) The analysis of relation between learning styles and media using by Pearson's correlation coefficient (r) from -1 to 1 / the minus score showed the negative relation and the plus score showed the positive relation of the variables.

$r=.50$ to 1.00 or $r=-.50$ to -1.00 refers to the relation of variables in high level $\mathrm{r}=.30$ to .49 or $\mathrm{r}=-.30$ to -.49 refers to the relation of variables in average level $r=.10$ to .29 or $r=-.10$ to -.29 refers to the relation of variables in low level $r=.00$ refers to no relation between variables

\section{RESEARCH FINDING}

The survey research on "The 21st Century Instruction: The Relationship Between Learning Style and Media Using" aimed to 1) study the learning style of the students, 2) study the media using of the students, 3) study the relationship between the learning style and media using. The researcher presented the data analysis as follow:

Section 1 Basic information - the data analysis of the 191 samples were as follow:

TABLE I: BASIC INFORMATION $(N=191)$

\begin{tabular}{ccc}
\hline \multicolumn{1}{c}{ Status } & Number & Percentage \\
\hline 1. sex & 39 & \\
male & 152 & 20.4 \\
female & $\mathbf{1 9 1}$ & 79.6 \\
\hline \multicolumn{1}{c}{ Total } & & 100.0 \\
\hline 2. level of study & 10 & 5.2 \\
$1^{\text {st }}$ year & 74 & 38.8 \\
$2^{\text {nd }}$ year & 45 & 23.6 \\
$3^{\text {rd }}$ year & 54 & 28.2 \\
$4^{\text {th }}$ year & 8 & 4.2 \\
$5^{\text {th }}$ year & $\mathbf{1 9 1}$ & 100.0 \\
\hline Total & &
\end{tabular}

\begin{tabular}{lrr} 
3. equipment used for access & & \\
online media & & \\
(more than 1 was accepted) & 151 & 52.8 \\
mobile phone & 11 & 3.8 \\
tablet & 124 & 43.4 \\
computer & & \\
\hline \multicolumn{1}{c}{ Total } & $\mathbf{2 8 6}$ & $\mathbf{1 0 0 . 0}$ \\
\hline 4. time of access online media & & \\
(more than 1 was accepted) & 184 & 21.5 \\
05.01-09.00 am. & 109 & 12.7 \\
09.01-am. -1 pm. & 98 & 11.5 \\
1.01 pm. - 5 pm. & 120 & 14.0 \\
5.01 - 9 pm. & 154 & 18.0 \\
9.01 pm. - 01.00 am. & 190 & 22.3 \\
01.01-05.00 am. & $\mathbf{8 5 5}$ & $\mathbf{1 0 0 . 0}$ \\
\hline$\quad$ Total & 108 & 56.6 \\
\hline T. How to learn (study) & 8 & 4.2 \\
Classroom & 75 & 39.2 \\
Individual study & & $\mathbf{1 0 0 . 0}$ \\
Both classroom and & $\mathbf{1 9 1}$ & \\
individual learning & & \\
\hline$\quad$ Total & & \\
\hline
\end{tabular}

Table I showed the data analysis of basic information of the samples. It was found that the samples were $20.3 \%$ male and $79.7 \%$ female. Most of the samples were $2^{\text {nd }}$ year students at $38.5 \%$. The samples used mobile phone as a tool for accessing the media at $52.8 \%$. Most of the samples accessed to online media at 01.01-05.00 am. at 22.3\%. And most of the samples participated the classroom at $56.7 \%$.

From Fig. 1 the data analysis on learning styles of the learners in overview was at the level of "much". ( $\bar{x}=3.92$, S.D. = .46) Considering in any learning styles, the learning style of KLS-Kinesthetic Learning Style was at the level of "much". $(\bar{x}=4.08$, S.D. $=.56)$ The less was GLS- Group Learning Style ( $\bar{x}=4.06$, S.D.=.65)and ALS- Audio 
Learning Style $(\bar{x}=4.05$, S.D. $=.52)$ respectively. And the ILS- Individual Learning Style was at the level of "least".

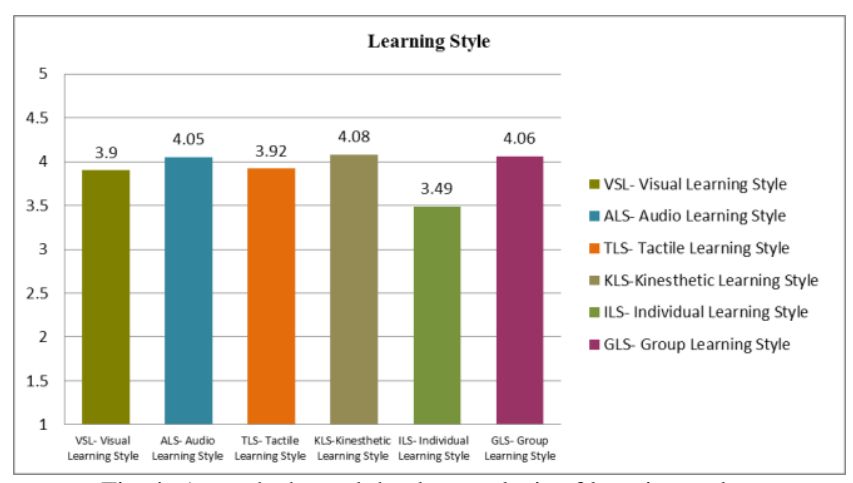

Fig. 1. A graph showed the data analysis of learning styles.

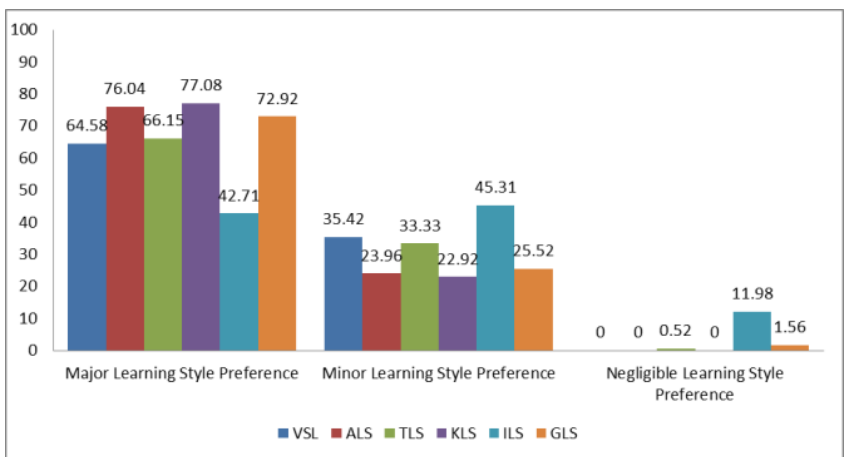

Fig. 2. The percentage of learning styles and the level of using learning styles.

From Fig. 2 the students from the Faculty of Education, Ramkhamhaeng University had learning styles and the level of using learning styles as follow: Most of the samples had Major Learning Style Preference as follow: KLS-Kinesthetic Learning Style was at $77.08 \%$, the less was ALS- Audio Learning Style at $76.04 \%$ and GLS- Group Learning Style at $72.92 \%$ respectively.

Most of the samples had Minor Learning Style Preference as follow: ILS- Individual Learning Style was at $45.31 \%$, VSL- Visual Learning Style was at $35.42 \%$, and TLS- Tactile Learning Style was at $33.33 \%$ respectively.

For Negligible Learning Style Preference, the most was ILS- Individual Learning Style at $11.98 \%$, the less was GLSGroup Learning Style, and TLS- Tactile Learning Style respectively.

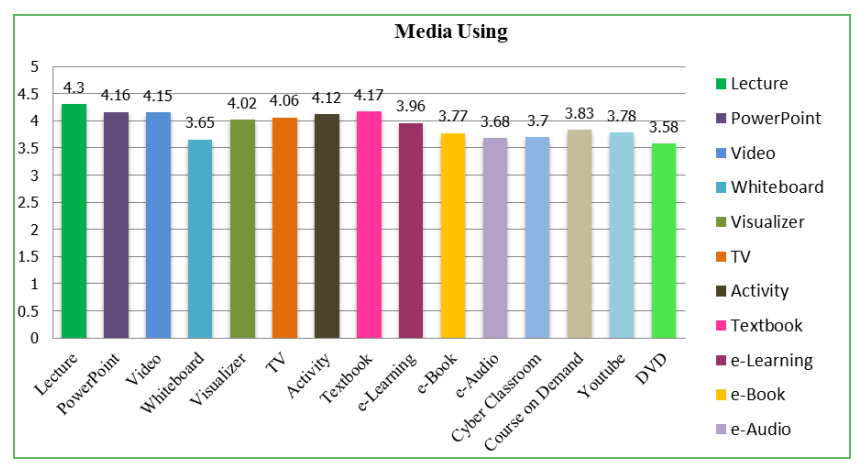

Fig. 3. A graph showed the data analysis of learning styles.

From Fig. 3 the data analysis on media using of undergraduate students, Faculty of Education, Ramkhamhaeng University found that overview of media using of the students was at the level of "much: Considering at the media using of undergraduate students Faculty of Education, Ramkhamhaeng University, the lecturing by instructor was mostly used at the level of "much" ( $\bar{x}=4.30$, S.D. $=0.73)$, the less was printed materials, textbook, leaning documents $(\bar{x}=4.17$, S.D. $=0.76)$, and PowerPoint $(\bar{x}=4.16$, S.D. $=0.82)$ respectively. The least used was DVD with narration.

TABLE II: BASIC THE DATA ANALYSIS ON RELATION BETWEEN LEARNING STYLES AND MEDIA USING

\begin{tabular}{|c|c|c|c|c|c|c|}
\hline \multirow{3}{*}{ Types of media } & \multicolumn{6}{|c|}{ Learning Style } \\
\hline & VSL & ALS & TLS & KLS & ILS & GLS \\
\hline & $\mathrm{r}$ & $\mathbf{r}$ & $\mathbf{r}$ & $\mathbf{r}$ & $\mathbf{r}$ & $\mathbf{r}$ \\
\hline $\begin{array}{l}\text { 1. Lecturing from } \\
\text { instructors }\end{array}$ & $\begin{array}{c}.36^{*} \\
*\end{array}$ & $\begin{array}{c}.43 * \\
*\end{array}$ & $\begin{array}{c}.38^{*} \\
*\end{array}$ & $\begin{array}{c}.46^{*} \\
*\end{array}$ & .12 & $\begin{array}{c}.46^{*} \\
*\end{array}$ \\
\hline $\begin{array}{l}\text { 2. Study with } \\
\text { PowerPoint in the } \\
\text { classroom }\end{array}$ & $\begin{array}{c}35^{*} \\
*\end{array}$ & $\begin{array}{c}.45^{*} \\
*\end{array}$ & $\begin{array}{c}.40^{*} \\
*\end{array}$ & $\begin{array}{c}.44^{*} \\
*\end{array}$ & $\begin{array}{c}15^{*} \\
*\end{array}$ & $\begin{array}{l}.50^{*} \\
*\end{array}$ \\
\hline $\begin{array}{l}\text { 3. Study with Video } \\
\text { in the classroom }\end{array}$ & $\begin{array}{c}.34^{*} \\
*\end{array}$ & $\begin{array}{c}.44^{*} \\
*\end{array}$ & $\begin{array}{c}.40^{*} \\
*\end{array}$ & $\begin{array}{c}.44^{*} \\
*\end{array}$ & $\begin{array}{c}.16^{*} \\
*\end{array}$ & $\begin{array}{c}.45^{*} \\
*\end{array}$ \\
\hline $\begin{array}{l}\text { 4. Study with White } \\
\text { Board in the } \\
\text { classroom }\end{array}$ & $\begin{array}{c}.46^{*} \\
*\end{array}$ & $\begin{array}{c}.42 * \\
*\end{array}$ & $\begin{array}{c}.44^{*} \\
*\end{array}$ & $\begin{array}{c}.34^{*} \\
*\end{array}$ & $\begin{array}{c}.34^{*} \\
*\end{array}$ & $\begin{array}{c}30^{*} \\
*\end{array}$ \\
\hline $\begin{array}{l}\text { 5. Study with } \\
\text { Visualizer in the } \\
\text { classroom }\end{array}$ & $\begin{array}{c}.42 * \\
*\end{array}$ & $\begin{array}{l}.44 * \\
*\end{array}$ & $\begin{array}{c}.54 * \\
*\end{array}$ & $\begin{array}{c}.47 * \\
*\end{array}$ & $\begin{array}{c}.14 * \\
*\end{array}$ & $\begin{array}{c}.45^{*} \\
*\end{array}$ \\
\hline $\begin{array}{l}\text { 6. Study with video } \\
\text { media in theclassroom }\end{array}$ & $\begin{array}{l}.39 * \\
*\end{array}$ & $\begin{array}{c}.48 * \\
*\end{array}$ & $\begin{array}{l}.47 * \\
*\end{array}$ & $\begin{array}{l}.48^{*} \\
*\end{array}$ & $\begin{array}{l}.22 * \\
*\end{array}$ & $\begin{array}{c}.48^{*} \\
*\end{array}$ \\
\hline $\begin{array}{l}\text { 7. Do learning } \\
\text { activities as the } \\
\text { instructors assigned in } \\
\text { the classroom }\end{array}$ & $\begin{array}{c}.43 * \\
*\end{array}$ & $\begin{array}{l}.42 * \\
*\end{array}$ & $\begin{array}{l}.57 * \\
*\end{array}$ & $\begin{array}{l}.54^{*} \\
*\end{array}$ & $\begin{array}{c}.26^{*} \\
*\end{array}$ & $\begin{array}{l}.50^{*} \\
*\end{array}$ \\
\hline $\begin{array}{l}\text { 8. Study with printed } \\
\text { materials, textbooks, } \\
\text { documents }\end{array}$ & $\begin{array}{c}.42 * \\
*\end{array}$ & $\begin{array}{c}.38^{*} \\
*\end{array}$ & $\begin{array}{c}.39 * \\
*\end{array}$ & $\begin{array}{c}.37 * \\
*\end{array}$ & $\begin{array}{c}.24 * \\
*\end{array}$ & $\begin{array}{l}.31 * \\
*\end{array}$ \\
\hline $\begin{array}{l}\text { 9. Study by } \\
\text { e-Learning }\end{array}$ & $\begin{array}{l}.41 * \\
*\end{array}$ & $\begin{array}{c}.44^{*} \\
*\end{array}$ & $\begin{array}{l}.42^{*} \\
*\end{array}$ & $\begin{array}{c}.38^{*} \\
*\end{array}$ & $\begin{array}{c}.28 * \\
*\end{array}$ & $\begin{array}{l}.36^{*} \\
*\end{array}$ \\
\hline $\begin{array}{l}\text { 10. Study with } \\
\text { e-Book }\end{array}$ & $\begin{array}{l}.51^{*} \\
*\end{array}$ & $\begin{array}{c}.49 * \\
*\end{array}$ & $\begin{array}{l}.51^{*} \\
*\end{array}$ & $\begin{array}{c}.44^{*} \\
*\end{array}$ & $\begin{array}{c}.33 * \\
*\end{array}$ & $\begin{array}{c}.48^{*} \\
*\end{array}$ \\
\hline $\begin{array}{l}\text { 11. Study with } \\
\text { e-Audio Book }\end{array}$ & $\begin{array}{c}.44^{*} \\
*\end{array}$ & $\begin{array}{c}.42 * \\
*\end{array}$ & $\begin{array}{c}.53^{*} \\
*\end{array}$ & $\begin{array}{c}.42^{*} \\
*\end{array}$ & $\begin{array}{c}.26^{*} \\
*\end{array}$ & $\begin{array}{c}.45^{*} \\
* \\
\end{array}$ \\
\hline $\begin{array}{l}\text { 12. Study by Cyber } \\
\text { Class Room }\end{array}$ & $\begin{array}{c}.36^{*} \\
*\end{array}$ & $\begin{array}{c}.38^{*} \\
*\end{array}$ & $\begin{array}{c}.34^{*} \\
*\end{array}$ & $\begin{array}{c}.33^{*} \\
*\end{array}$ & $\begin{array}{c}.28 * \\
* \\
\end{array}$ & $\begin{array}{c}.29 * \\
*\end{array}$ \\
\hline $\begin{array}{l}\text { 13. Study with Course } \\
\text { on Demand } \\
\text { (m-Learning) }\end{array}$ & $\begin{array}{c}.42 * \\
*\end{array}$ & $\begin{array}{c}.35^{*} \\
*\end{array}$ & $\begin{array}{c}.27 * \\
*\end{array}$ & $\begin{array}{c}.30^{*} \\
*\end{array}$ & $\begin{array}{c}.34 * \\
*\end{array}$ & $\begin{array}{c}.19^{*} \\
*\end{array}$ \\
\hline $\begin{array}{l}\text { 14. Study with } \\
\text { YouTube of RU } \\
\text { Channel }\end{array}$ & $\begin{array}{c}.28^{*} \\
*\end{array}$ & $\begin{array}{c}.33^{*} \\
*\end{array}$ & $\begin{array}{c}.36^{*} \\
*\end{array}$ & $\begin{array}{c}.38^{*} \\
*\end{array}$ & $\begin{array}{c}.23 * \\
*\end{array}$ & $\begin{array}{c}.36^{*} \\
*\end{array}$ \\
\hline $\begin{array}{l}\text { 15. Study with DVD } \\
\text { with narration }\end{array}$ & $\begin{array}{c}.34^{*} \\
*\end{array}$ & $\begin{array}{c}.33 * \\
*\end{array}$ & $\begin{array}{c}.40^{*} \\
*\end{array}$ & $\begin{array}{c}.36^{*} \\
*\end{array}$ & $\begin{array}{c}.27 * \\
*\end{array}$ & $\begin{array}{c}.34 * \\
*\end{array}$ \\
\hline
\end{tabular}

From Table II, the data analysis on relation between learning styles and media using found the learning styles and media using related significantly at the level of .01. in any item, the learning style of TLS related mostly to the learning activities as the instructors assigned in the classroom. $(r$ $=.57$ ) The less was the relation between the learning style of TLS and the study with visualizer in the classroom $(r=.54)$, The next was learning style of ILS related to the learning activities as the instructors assigned in the classroom $(r=.54)$, and the learning style of TLS related to the study with e-Audio Book respectively. And the last, learning style of ILS had no relation to the lecturing from instructors.

\section{RESEARCH DISCUSSION}

1) The study on learning style of undergraduate students, 
Faculty of Education, Ramkhamhaeng University, found that the learning style of KLS-Kinesthetic Learning Style was at the level of "much: $(\bar{x}=4.08$, S.D.=.56), the less was learning style of GLS- Group Learning Style $(\bar{x}=$ 4.06, S.D. $=.65)$ and learning style of ALS- Audio Learning Style $(\bar{x}=4.05$, S.D. $=.52)$ respectively. The learning style of ILS- Individual Learning Style had lowest mean which was harmonized to the research of [2], [3] that studied the learning style in English of the students and found the students agreed with learning style of GLS, KLS, and ASL. The learning style of ILS had the lowest mean. In addition, [1] had studied on the learning styles of Chinese students in the undergraduate study of the University in USA and found the students agreed with learning style of KLS and TLS but the students did not like the learning style of GLS.

From the result, the undergraduate students, Faculty of Education, Ramkhamhaeng University, had KLS-Kinesthetic learning style that the learners participated and learned in the classroom. The students also had learning style of GLS to work together with classmate and solve the problem in team to learn new things individually. The learning motivation and cooperation among group could stimulate the group to learn. The students also agreed with the learning style of ALS that learned by listening such as lecturing of instructors, conversation, tape recording, and assignment. This was harmonized to the study on media using which the lecturing in the classroom was the mostly used. [4] also studied the learning style of Japanese students in the university and found the students had the learning style of ALS. And the last, ILS- Individual Learning Style was the lowest which was harmonized to the use of DVD with narration for individual study that was the least used.

On the level of media using according to the learning styles found that most of the samples had Major Learning Style Preference as follow: KLS-Kinesthetic Learning Style was at $77.08 \%$, the less was ALS- Audio Learning Style at 76.04\% and GLS- Group Learning Style at $72.92 \%$ respectively. This was harmonized to [5] that studied the learning styles of undergraduate students majored in science and technology in Thailand which studied as EFL students. The study found that the undergraduate students majored in science and technology in Thailand agreed with many learning styles. The most was GLS and the least was ILS. The result was harmonized to Negligible Learning Style Preference that ILS- Individual Learning Style was the least at $11.98 \%$. [2] mentioned the students with learning style of Minor Learning Style Preference and Major Learning Style Preference had good characteristics of learning style to perceive the learning information. For the students with no learning style, they would be not able to learn or perceive any information while learning.

2) The overview result on media using of undergraduate students, Faculty of Education, Ramkhamhaeng University, was at the level of "much". Considering at the media, the most media used was lecturing in the classroom which was at the level of "much". $(\bar{x}=4.30$, S.D. $=0.73)$ The less was printed materials, textbooks and documents $(\bar{x}=4.17$, S.D. $=0.76)$ and the use of
PowerPoint in the classroom $(\bar{x}=4.16$, S.D. $=0.82)$ respectively. The least used was DVD with narration which might be caused by the students in teaching profession that get familiar with lecturing in the classroom and gain experience of teaching and enhance the profession of them. So the instructors should provide the learning activity to let he students participate the learning process and connect learning to the online media to search information for learning individually and lead to extend knowledge learned as a dynamic to study outside of the classroom. The learning activity might be group working to find the answer or cooperate to summarize and reflect the knowledge (sharing knowledge). The research also found the increasing of media

Using of e-Learning, e-Book, e-Audio Book, Cyber Class Room, Course on Demand (m-Learning), and YouTube (RU Channel). Those of media was the appropriate technology for supporting the learning management not even in the classroom and also response the students who cannot attend the classroom and suited for individual study.

3) The study on relation between learning styles and media using of the undergraduate students, Faculty of Education, Ramkhamhaeng University found that the learning style of TLS had mostly related to the lecturing in the classroom. ( $r=.57)$ The less was learning style of TLS related to the use of visualizer in the classroom $(r=.54)$, the learning style of KLS related to doing learning activities as the instructors assigned in the classroom $(r$ $=.54$ ) and the learning style of TLS related to the use of e-Audio Book respectively. And the learning style of ILS had no relation to the lecturing in the classroom. From the research result, the learning style of TLS which learned by doing such as the Buddha Image casting, laboratory and learning by the real object such a pictorial book, flashcard. The learners of this learning style learned by doing instead of reading, listening from instructors. The learners were happy to invent things individually. This was mostly related to the learning assignment of instructors included the use of visualizer in the classroom. Similar to the learning style of KLS; learning from experience and participate in learning activity, will memorize by the method of learning with excursion or mix method such as using tape recording and other learning activity. This mix method lead KLS learning style related to learning activity in the classroom. [6] advised knowledge and understanding were the most important for the classroom and technology also effected the learning attendance of the learners. The instructors should use many styles of teaching by student centered approach and challenge the students to learn. The knowing of learning style of learners is essential for learning management. The learners will adapt the learning style and the instructors are able to choose the instructional strategy for the learners and gain effective learning at last.

Moreover, the instructors should adapt the instructional strategy related to the use of technology to provide in the learning management. The classroom activity such as project-based learning, problem based learning can be applied in learning management and learning environment to 
let the learners participate in learning process. In the $21^{\text {st }}$ century, the learning management objectives are to create 3 skills for life; learning and innovation skill, computer technology and information skill, and life and professional skill. The instructors should support the learners to gain those 3 skills and the university should develop the instructional media service to relate the learning styles of learners. The consideration of media use and accessing media should be valuable in media production and can be able to support learning process and stimulate learners through learning activities and media as well.

\section{SUGgestion}

1) The learning process should relate to the learning styles of learners. So the learning style of KLS-Kinesthetic Learning Style, GLS- Group Learning Style, ALS- Audio Learning Style can enhance learning achievement. The instructors should apply the research result and adapt in instructional management in any subject effectively.

2) A development of media production should harmonize to the learning style of learners for effective learning management.

3) The future research should concern the instructional strategy that related to the instructional system of undergraduate study.

\section{REFERENCES}

[1] J. M. Reid, "The learning style preferences of ESL students," TESOL Quarterly, vol. 21, pp. 87-111, 1987.

[2] N. Munsakorn, "Background and English Learning Styles of Bangkok University Students," Research Report, Bangkok University, Bangkok, Thailand, 2010.

[3] A. Arunreung, W. Sangounpong, and Wichiranon, "English language learning styles of liberal arts students, Rajamangala University of Technology PhraNakhon," Research Report. Rajamangala University of Technology Phra Nakhon., Bangkok, Thailand, 2013.

[4] K. Hyland, "Culture and learning: A study of the learning style preferences of Japanese students," RELC Journal, vol. 24, no. 2, pp. 69-91, 1993.

[5] S. Akkakoson, "A study of perceptual learning style preferences of Thai EFL university students of science and technology disciplines," Research report, King Mongkut's University of Technology North Bangkok., Bangkok, Thailand, 2012.

[6] G. A. Pourhossein and L. Branch, "Visual, auditory, kinaesthetic learning styles and their impacts on English language teaching," Journal of Studies in Education, vol. 2, no. 1, pp. 104-113, August 2012.

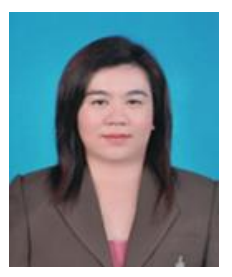

Sayamon Insaard is a lecturer in the Department of Technology, Faculty of Education, Ramkhamhaeng University, Thailand. She received Doctor of Philosophy in Education Program (Educational Technology and Communications) from the Chulalongkorn University, Thailand. Her research interests include research topics of e-learning, e-training, professional learning community (PLC), learning style and higher order thinking. 